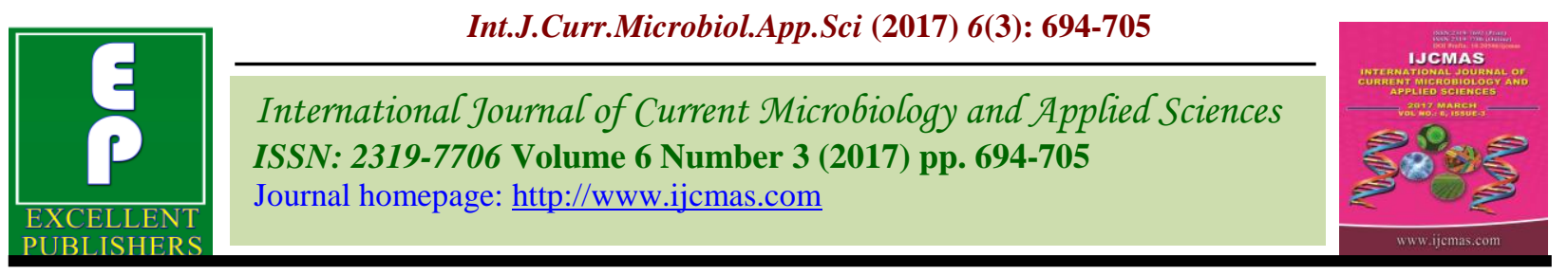

Original Research Article

https://doi.org/10.20546/ijcmas.2017.603.080

\title{
Survey, Virulence and Pathogenicity of Root Rot Incidence of Cowpea in Selected Districts of Tamilnadu caused by Macrophomina phaseolina (Tassi.) Goid
}

\author{
R. Mohanapriya ${ }^{1}$, R. Naveenkumar ${ }^{2}$ and P. Balabaskar ${ }^{3}$ \\ ${ }^{1}$ Department of Plant Pathology, S Thangapazham Agricultural College, Vasudevanallur, \\ Tirunelveli-627760, Tamil Nadu \\ ${ }^{2}$ Department of Mycology and Plant Pathology, I. Ag. Sci., Banaras Hindu Universiy, \\ Varanasi-221005, India \\ ${ }^{3}$ Department of Plant Pathology, Faculty of Agriculture, Annamalai University, \\ Annamalainagar, Chidambaram, Tamil Nadu, India-608 002 \\ *Corresponding author
}

\section{A B S T R A C T}

\section{Keywords}

Cowpea, Root rot,

Virulence,

Sclerotia,

Pathogenecity,

Disease incidence.

Article Info

Accepted:

15 February 2017

Available Online:

10 March 2017
Cowpea (Vigna unguiculata (L.)Walp.) is a poor men's protein source. It is one of the most ancient human food sources and an important grain legume and hay crop in many tropical and subtropical regions. It is grown in Tamil Nadu and Andhra Pradesh widely as rainfed crop. Cowpea is affected by many diseases caused by viruses, bacteria and fungi. Among the fungal diseases, the charcoal rot caused by Macrophomina phaseolina (Tassi.) Goid causes significant loss in yield. M. phaseolinais a soil borne plant pathogen with a very wide host range. The studies were initiated with survey on the dry root rot incidence of cowpea in Cuddalore, Thiruvannamalai and Vellore districts of Tamil Nadu revealed endemic nature of the root rot disease incidence of cowpea. Among the different locations of Cuddalore, Thiruvannamalai and Vellore districts surveyed for cowpea root rot incidence, Sukkanampatti $\left(\mathrm{MP}_{10}\right)$ registered the maximum incidence of the disease (25.84\%) followed by Keelakalpoondi, Keeranur and Sivapuri. The other locations viz., Kadavacheri, Perumathur, Varakoorpettai and Simanamputhur had moderate disease incidence while the minimum root rot incidence was recorded in Thanippadi and Chittur. In general, the crop grown under rainfed conditions showed more root rot incidence when compared with the crops grown under irrigated conditions. The variations in root rot incidence could be well attributed to the difference in virulence of the isolates of $M$. phaseolina prevalent in the respective areas. The survey revealed that higher levels of disease incidence in rainfed crop than that of irrigated crop. The dry condition prevalent in the rainfed conditions might have favoured the pathogen which could be attributed as the reason for the higher level of disease incidence.

\section{Introduction}

Cowpea (Vigna unguiculata (L.)Walp.) is a poor men's protein source. It is one of the most ancient human food sources $(\mathrm{Ng}$ and Marechal, 1985) and an important grain legume and hay crop in many tropical and subtropical regions (Fang et al., 2007). Although cowpea is cultivated worldwide, over $75 \%$ of the world production is obtained from Africa (Singh et al., 2002). In Africa it is considered the second most important pulse 
crop and ranked amongst the top-five most important legumes in the world (Awurum and Enyiukwu, 2013). Among the various pulse crops, cowpea (southern pea) is one of the important crop and is grown in Tamil Nadu and Andhra Pradesh widely as rainfed crop.

The name "Cowpea" probably derived from when it was an important livestock feed for cows in the United States. Cowpea is called the "hungry-season crop" because it is the first crop to be harvested before the cereal crops (Gomez, 2004).

Cowpea is a good source of food, forage, fodder, vegetable and certain snacks (Nirmalet al., 2001). Cowpea pod husks obtained after threshing are also used to feed livestock. It is a crop of low and high rainfall regions, an important component of cropping system grown as catch crop, mulch crop, intercrop, mixed crop and green crop. It has the ability to fix atmospheric nitrogen in soil at the rate of $56 \mathrm{~kg}$ per ha in association with symbiotic bacteria under favourable conditions through its root nodules (Ahlawat and Shivkumar, 2005; Fatokumet al., 2000). It grows well in poor soils with more than $85 \%$ sand and with less than $0.2 \%$ organic matter and low phosphorus. According to FAOSTAT (2013), worldwide green pod production in 2010 was 4.5 million tons, cultivated in approximately 8 million hectares intended for human consumption.

Area under cowpea in India is 3.9 million hectares with a production of 2.21 million tonnes with the national productivity of 683 kg per ha (Anil Kumar Singh, et al., 2012).

Cowpea is attacked by many diseases caused by viruses, bacteria and fungi (Emechebe and Lagoke, 2002). In India, cowpea and other pulse crops are mostly cultivated under rainfed conditions accounting above $78 \%$ of area and being a tropical environment, favours the disease incidence. Among the fungal diseases, the charcoal rot caused by Macrophomina phaseolina (Tassi.) Goid causes significant loss in yield. Concurrent heat and moisture stress favor development of charcoal or dry root rot caused by $M$. phaseolina often makes cultivation of cowpea uneconomical (Singh et al., 2012). Incidence of this disease ranging from 5 to 39 per cent, cowpea crop has been reported (Ushamalini et al., 2001).

M. phaseolina is a soil borne plant pathogen with a very wide host range. $M$. phaseolina attacks a variety of oil seed, legumes and vegetable crops, besides a wide range of unrelated plants. Its microsclerotia, formed in senescing shoot tissues, survive well in soil (Mayek-Perez et al., 2002).The fungus is soilborne and poses great problem in managing the disease. During the recent years this disease causes significant losses in cowpea growing areas of Cuddalore, Thiruvannamalai and Vellore Districts.

Hence, the present study was conducted with an objective to assess the prevalence and incidence of dry root rot of cowpea in Cuddalore, Thiruvannamalai and Vellore Districts, India during 2013-14 and assess the cultural characters and pathogenic variability among the isolates of $M$. phaseolina.

\section{Materials and Methods}

\section{Survey for assessment of loss due to dry root rot disease incidence}

A field survey was conducted during 2013 14 to assess the extent of root rot occurrence of cowpea in Cuddalore, Thiruvannamalai, and Vellore districts of Tamil Nadu state. Ten locations representing both rainfed and irrigated situations were selected for the study. The per cent disease incidence was worked out using the following formula 
Per cent Disease Incidence $(\mathrm{PDI})=$

$\frac{\text { Noof diseased plants }}{\text { Noof plantsobserved }} \times 100$

Also, the infected plants showing the typical symptoms of root rot due to infection with $M$. phaseolina were collected along with rhizosphere soil for isolation of the pathogen. The other informations regarding the soil type in which the crop is grown and the variety of cowpea cultivated were also recorded in the respective survey fields.

\section{M. phaseolina isolate}

The pathogen $M$. phaseolina (Tassi) Goid was isolated from the diseased roots of cowpea plants showing the typical root rot symptoms by tissue segment method on potato dextrose agar (PDA) medium. The axenic cultures of the different isolates of the pathogen were obtained by single hyphal tip method (Rangaswami, 1972) and these were maintained on PDA slants for subsequent experiments.

\section{Mass multiplication of $M$. phaseolina inoculum for soil application}

The isolates of the pathogen were multiplied in sand maize medium (Riker and Riker, 1936). Sand and ground maize seeds were mixed in the ratio of $19: 1$, moistened to 50 per cent moisture content, filled in $500 \mathrm{ml}$ conical flask and autoclaved at 20 psi for two h. Four actively growing mycelial discs (9 $\mathrm{mm}$ ) of the pathogen isolates were inoculated into each flask under aseptic condition and the flasks were incubated at room temp. (28 \pm $2^{\circ} \mathrm{C}$ ) for 15 days and the incoulum thus obtained was used for the experiments.

\section{Pathogenicity test}

Pots $(30 \mathrm{~cm}$ dia) of uniform size containing sterilized soil were used for proving pathogenecity. The inoculum of M.phaseolina isolates multiplied in sand maize medium was mixed with soil @ 5\% level ratio at the time of sowing (Sankar, 1994). About 2 cowpea seeds were sown in each pot and maintained in green house with need based irrigation. The PDI was assessed at 30, 60 and 90 DAS and recorded. Also the plants showing the typical root rot symptom were pulled out and the pathogen was re-isolated on PDA slants. The culture thus obtained was compared with that of the original culture and the pathogenecity (Koch postulates) was proved.

\section{Cultural characteristics of the isolates}

\section{Morphological characters on PDA}

Fifteen $\mathrm{ml}$ of the medium was poured into each of the $90 \mathrm{~mm}$ Petri dishes. One $\mathrm{ml}$ of streptomycin sulphate of $100 \mathrm{ppm}$ strength was added to the medium just before pouring into the plates. Inoculation was made by transferring $9 \mathrm{~mm}$ growth disc of $M$. phaseolina taken from the periphery of seven day old culture. The plates were incubated at $28 \pm 2{ }^{0} \mathrm{C}$. Differences in topography, type of margin, rate of growth and days to form sclerotia were recorded.

\section{Mycelial growth}

Fifteenml of the sterilized PDA medium was poured into sterile Petri dishes and allowed to solidify. A nine $\mathrm{mm}$ culture disc of $M$. phaseolina obtained from actively growing region was aseptically placed at the center of the dish and incubated at room temperature $\left(28 \pm 2{ }^{\circ} \mathrm{C}\right)$. The radial growth of the isolates (in $\mathrm{mm}$ ) was measured four days after inoculation.

\section{Sclerotial number}

Four culture discs $(9 \mathrm{~mm})$ were cut and placed into $50 \mathrm{ml}$ beakers containing $10 \mathrm{ml}$ of sterile water. These beakers were kept on a 
mechanical shaker at $1000 \mathrm{rpm}$ for $30 \mathrm{~min}$. to separate the sclerotia from the medium; then squeezed through cheese cloth; washed several times with distilled water and the sclerotia were transferred to a glass vial containing $2.5 \mathrm{ml}$ of 2.5 per cent ammonium sulphate.

After $10 \mathrm{~min}$. the floating sclerotia were filtered through a Whatman No. 42 filter paper rinsed with dist. water and the number of sclerotia was counted using stereo zoom microscope (Dhingra and Sinclair, 1978). The time taken by the isolates to form sclerotia was also recorded. The number of sclerotia per microscopic field and per nine $\mathrm{mm}$ disc were assessed and recorded.

\section{Sclerotial size}

For each isolate 100 sclerotia were collected at random. These were dried under shade for two h. and their size was measured using an ocular micrometer in a calibrated microscope.

\section{Optimum inoculum level of M. phaseolina}

The sand maize inoculum of the most virulent isolate $\left(\mathrm{MP}_{10}\right)$ of $M$. phaseolina at different levels was separately mixed thoroughly with the sterile and unsterile pot culture soil in earthen pots one week prior to sowing. Four surface sterilized seeds were sown in each pot. Three replications were maintained for each treatment and the pots were maintained under glass house conditions. The disease incidence at 30 days interval up to 90 DAS and expressed as per cent disease incidence. The optimum inoculum level identified from these experiments was used in all the subsequent experiments of this study.

\section{Statistical analysis}

The data collected were subjected to statistical analysis using computer aided AGRISTAT (V.6.2003) software.

\section{Results and Discussion}

Survey on the dry root rot incidence of cowpea in Cuddalore, Thiruvannamalai and

\section{Vellore districts of Tamil Nadu}

The data presented in table 1 on the survey in different locations of Cuddalore, Thiruvannamalai and Vellore districts revealed endemic nature of the root rot disease incidence of cowpea. Among the different locations of Cuddalore, Thiruvannamalai and Vellore districts surveyed for cowpea root rot incidence, Sukkanampatti $\left(\mathrm{MP}_{10}\right)$ registered the maximum incidence of the disease $(25.84 \%)$ followed by Keelakalpoondi $\left(\mathrm{MP}_{1}\right)$ with 25.43 per cent, Keeranur $\left(\mathrm{MP}_{8}\right)$ with 24.41 per cent and Sivapuri $\left(\mathrm{MP}_{4}\right)$ with 23.75 per cent. The other locations viz., Kadavacheri (23.42), Perumathur (22.82), Varakoorpettai (21.48) and Simanamputhur (20.56) had moderate disease incidence while the minimum root rot incidence of 19.38 and 17.72 per cent was recorded in Thanippadi and Chittur. In general, the crop grown under rainfed conditions showed more root rot incidence when compared with the crops grown under irrigated conditions. In respect of soil type, sandy loam had more root rot incidence (17.72 to $25.84 \%$ ) than red sandy $(24.41 \%)$, clay loam (21.48 to $25.43 \%)$ and clay (22.82 to $23.75 \%)$.

The variations in root rot incidence could be well attributed to the difference in virulence of the isolates of $M$. phaseolina prevalent in the respective areas. The severity of the disease is also directly related to the population of viable sclerotia in the soil (Salik Nawaz Khan, 2007). The survey revealed higher levels of disease incidence in rainfed crop than that of irrigated crop. The dry condition prevalent in the rainfed conditions might have favoured the pathogen which 
could be attributed as the reason for the higher level of disease incidence. Soil texture also had a significant impact on root infections. In the present survey more root rot disease incidence was observed in sandy loam as compared to clay or clay loam (Table 1). Similar to the present results, the crop grown in sandy loam soil registered higher per cent of root rot incidence than that of clay soil (Rettinasababady and Ramdoss, 1999).Cruz Jimenez (2011) observed highest $M$. phaseolina root populations in sandy soils, followed by loamy sand and loam soil textures. These earlier reports lend support to the present findings.

\section{Pathogenecity of M. phaseolina isolates}

The data depicted in table 2 revealed varied levels of pathogenicity with difference in isolates. Among the ten isolates of $M$. phaseolina collected from different conventional cowpea growing areas of Cuddalore, Thiruvannamalai and Vellore district, the isolate $\left(\mathrm{MP}_{10}\right)$ collected from Sukkanampatti was found to be more virulent and recorded the maximum incidence of 48.60 per cent (at 90 DAS) followed by $\mathrm{MP}_{1}$ $(44.75 \%)$ collected from Keelakalpoondi. The isolate $\mathrm{MP}_{2}$ collected from Chittur was the least virulent which recorded the minimum $(24.33 \%)$ root rot disease incidence.

The results of the pot culture experiment conducted by artificial inoculation of the pathogen revealed varied levels of pathogenicity with different isolates. The variation in the isolates of $M$. phaseolina from different cowpea growing areas of Udaipur was reported by Ratnoo et al., (1997).

Generally, variability in the pathogenicity among the isolates of $M$. phaseolina was reported by earlier workers (Su et al., 2001; Chowdary, 2009; Rayatpanah and Dalili, 2012). The above reports are in agreement with the present investigation.Besides an increase in the root rot incidence was observed with an increase in the age of the crop. Similar to the present observation Rettinasababady and Ramadoss (2000), observed significant increase in root rot incidence at $40^{\text {th }}$ and $60^{\text {th }}$ DAS in rice fallow blackgram.

\section{Cultural characteristics of Macrophomina phaseolina isolates}

\section{Mycelial growth}

All the ten isolates of the root rot pathogen $M$. phaseolina produced white, whitish grey, grey, black scanty to profusely aerial mycelial growth on Potato Dextrose Agar (PDA) medium. The isolate of $\mathrm{MP}_{10}$ significantly recorded the maximum $(90 \mathrm{~mm})$ mycelial growth, while it was the minimum $(72.60 \mathrm{~mm})$ in the case of $\mathrm{MP}_{2}$. The other isolates showed moderate mycelial growth (80.60 to $88.25 \mathrm{~mm}$ ) (Table 3).

Similar such variation in the cultural characteristics of $M$. phaseolina on PDA was reported by Tandel et al., (2012). Also, several earlier workers have reported about the variations in the mycelial growth among the isolates of $M$. phaseolina (Edraki and Banihashemi, 2010; Ijaz et al., 2012). M. phaseolina isolates from pearl millet, sesame, horsegram and mothbean differed in their mycelial growth and showed marked variation in cultural characters (Sharma and Dureja, 2004). Shekhar et al., (2006) on the basis of colony colour divided seven isolates into four groups namely grayish white, blackish gray, dark black and cottony white colonies while working with charcoal rot of maize. Further, it was observed that the isolates of $M$. phaseolina with faster mycelial growth were more pathogenic and produced higher root rot incidence. 
The virulence of the isolates of $M$. phaseolina was positively correlated with their growth rate (Ghosh and Sen, 1973) and Sharmishha et al., (2004) reported that the isolates of $M$. phaseolina with faster mycelial growth were found more pathogenic to cluster beans. These earlier reports corroborate with the present findings.

\section{Sclerotial number}

All the isolates of $M$. phaseolina varied in their ability to produce sclerotia on PDA medium. The maximum sclerotial number of 183.50 per nine mm culture disc was obtained from $\mathrm{MP}_{10}$ which was also the most virulent isolate. This was followed by the isolates $\mathrm{MP}_{1}, \mathrm{MP}_{8}, \mathrm{MP}_{4}, \mathrm{MP}_{5}, \mathrm{MP}_{6}, \mathrm{MP}_{3}, \mathrm{MP}_{9}$, and $\mathrm{MP}_{7}$ which produced 178.25, 169.00. 168.75, $164.75,162.50,160.25,159.75$ and 158.25 numbers of sclerotia, respectively. The minimum number of sclerotia of 147.25 was recorded by $\mathrm{MP}_{2}$ the least virulent isolate (Table 3). It is evident from the observations that sclerotia are the primary means of survivial (Mirza, 1984) and sufficient build up of the growth is absolutely necessary for the aggressiveness of the pathogen. Generally isolates producing more sclerotia are more pathogenic and caused higher seedling mortality (Sharmishha et al., 2004). Hooda and Grover (1982) observed a positive correlation between the disease intensity and the inoculum density. Similarly, the correlation between inoculum density and disease development was reported in sesame (Sankar, 1994) and in other crops (Umamaheswari, 1991; Rettinasababady, 1996) in respect of $M$. phaseolina. Generally isolates producing more sclerotia are more pathogenic and caused higher seedling mortality as reported by Sharmishha et al., (2004). Also, the severity of the disease is directly related to the population of viable sclerotia in the soil (Sundravadana et al., 2012). In line with these earlier reports, in the present observation also the isolate which produced the maximum sclerotia happens to be the most virulent isolate.

\section{Sclerotial size}

The isolates of $M$. phaseolina produced varying sizes of sclerotia on PDA. The most virulent isolate $\mathrm{MP}_{10}$ produced the biggest sclerotia with a size of $104.20 \mu$ (Table 3) and the smallest sclerotial size of $78.20 \mu$ was recorded with $\mathrm{MP}_{2}$, which was the least virulent isolate. This was followed by other isolates viz., $\mathrm{MP}_{1}, \mathrm{MP}_{8}, \mathrm{MP}_{4}, \mathrm{MP}_{5}, \mathrm{MP}_{6}, \mathrm{MP}_{3}$, $\mathrm{MP}_{9}$, and $\mathrm{MP}_{7}$ which produced sclerotia with the size of $96.50,89.60,86.20,83.60,82.40$, $80.80,80.28$ and $80.06 \mu$, respectively. Similar variation in the sclerotial size of $M$. phaseolina was observed by several workers (Suriachandraselvan and Seetharaman, 2003; Tandel et al., 2012). Significant differences in mycelial development, size of sclerotia and pathogenecity of different isolates of $M$. phaseolina from cotton was observed by Vilela et al., (1987). All these above reports corroborate with the present findings.

The isolates producing bigger sclerotia caused more root rot incidence in cotton even at low inoculum level (Monga and Sheo Raj, 1994). In the present study also the isolate $\left(\mathrm{MP}_{10}\right)$, which produced the biggest sclerotia caused the maximum root rot incidence. The possibility of containing more food materials and subsequent production of more germ tubes by bigger sclerotia might have resulted in more aggressiveness of the isolate.

Effect of inoculums level of against $M$. phaseolina on the root rot incidence of cowpea

The data depicted in table 4 revealed that the inoculum level of $M$. phaseolina on the root rot incidence of cowpea showed variation in the level of root rot incidence with difference in the inoculum level. 
Table.1 Survey on the incidence of Dry root rot of cowpea in Cuddalore, Thiruvannamalai and Vellore Districts

\begin{tabular}{|c|c|c|c|c|c|c|c|}
\hline & $\begin{array}{l}\text { Isolate } \\
\text { number }\end{array}$ & Villages & Districts & Soil type & Variety & Situation & $\begin{array}{c}\text { Dry root rot incidence } \\
(\%)\end{array}$ \\
\hline 1 & $\mathrm{MP}_{1}$ & Keelakalpoondi & Cuddalore & Clay loam & $\begin{array}{c}\text { Local } \\
\text { variety }\end{array}$ & Rainfed & 25.43 \\
\hline 2 & $\mathrm{MP}_{2}$ & Chittur & Cuddalore & Sandy loam & $\begin{array}{c}\text { Local } \\
\text { variety }\end{array}$ & Irrigated & 17.72 \\
\hline 3 & $\mathrm{MP}_{3}$ & Varakoorpettai & Cuddalore & Clay loam & Co 6 & Rainfed & 21.48 \\
\hline 4 & $\mathrm{MP}_{4}$ & Sivapuri & Cuddalore & Clay & $\begin{array}{c}\text { Local } \\
\text { variety }\end{array}$ & Rainfed & 23.75 \\
\hline 5 & $\mathrm{MP}_{5}$ & Kadavacheri & Cuddalore & Clay & $\begin{array}{c}\text { Local } \\
\text { variety }\end{array}$ & Rainfed & 23.42 \\
\hline 6 & $\mathrm{MP}_{6}$ & Perumathur & Cuddalore & Clay & $\begin{array}{c}\text { Local } \\
\text { variety }\end{array}$ & Rainfed & 22.82 \\
\hline 7 & $\mathrm{MP}_{7}$ & Thanippadi & Thiruvannamalai & Sandy loam & Co 6 & Irrigated & 19.38 \\
\hline 8 & $\mathrm{MP}_{8}$ & Keeranur & Thiruvannamalai & Red sandy & Paiyur 1 & Rainfed & 24.41 \\
\hline 9 & $\mathrm{MP}_{9}$ & Simanamputhur & Vellore & Sandy loam & $\begin{array}{c}\text { Local } \\
\text { variety }\end{array}$ & Rainfed & 20.56 \\
\hline 10 & $\mathrm{MP}_{10}$ & Sukkanampatti & Vellore & Sandy loam & $\begin{array}{c}\text { Local } \\
\text { variety }\end{array}$ & Rainfed & 25.84 \\
\hline
\end{tabular}


Table.2 Pathogenicity of M. phaseolinaisolates

\begin{tabular}{|c|c|c|c|c|c|}
\hline \multirow{2}{*}{ S.No. } & \multirow{2}{*}{ Isolates } & \multicolumn{3}{|c|}{ Root rot incidence (\%) } & \multirow{2}{*}{ Mean } \\
\hline & & 30 DAS & $60 \mathrm{DAS}$ & 90 DAS & \\
\hline 1 & $\mathrm{MP}_{1}$ & $21.00(27.28)$ & $36.75(37.33)$ & $44.75(42.00)$ & 34.16 \\
\hline 2 & $\mathrm{MP}_{2}$ & $12.22(20.47)$ & $18.45(25.65)$ & $24.33(29.55)$ & 18.33 \\
\hline 3 & $\mathrm{MP}_{3}$ & $15.75(23.39)$ & $24.60(29.73)$ & $35.88(36.79)$ & 25.41 \\
\hline 4 & $\mathrm{MP}_{4}$ & $18.40(25.50)$ & $28.10(32.03)$ & $38.24(38.19)$ & 28.24 \\
\hline 5 & $\mathrm{MP}_{5}$ & $18.00(25.10)$ & $26.88(31.24)$ & $38.00(38.06)$ & 27.63 \\
\hline 6 & $\mathrm{MP}_{6}$ & $16.80(24.20)$ & $26.20(30.79)$ & $36.25(37.03)$ & 26.42 \\
\hline 7 & $\mathrm{MP}_{7}$ & $12.25(20.50)$ & $22.00(27.97)$ & $32.00(34.45)$ & 22.08 \\
\hline 8 & $\mathrm{MP}_{8}$ & $20.80(27.13)$ & $34.00(35.67)$ & $38.60(38.41)$ & 31.13 \\
\hline 9 & $\mathrm{MP}_{9}$ & $14.90(22.17)$ & $22.75(28.50)$ & $34.10(35.73)$ & 23.92 \\
\hline 10 & $\mathrm{MP}_{10}$ & $25.90(30.59)$ & $38.65(38.45)$ & $48.60(44.20)$ & 37.72 \\
\hline & S.Ed. & 0.08 & 0.09 & 0.10 & - \\
\hline & C.D. $(p=0.05)$ & 0.18 & 0.19 & 0.22 & - \\
\hline
\end{tabular}

Data in parentheses indicate arcsine transformed values

DAS - Days after sowing 
Table.3 Cultural characters of M.phaseolina isolates

\begin{tabular}{|c|c|c|c|c|c|}
\hline S.No. & $\begin{array}{c}\text { Isolate } \\
\text { number }\end{array}$ & $\begin{array}{c}\text { Mycelial } \\
\text { growth(mm) }\end{array}$ & $\begin{array}{c}\text { Number of } \\
\text { sclerotia } \\
(\mathbf{9} \text { mm disc) }\end{array}$ & $\begin{array}{c}\text { Sclerotial } \\
\text { size }(\boldsymbol{\mu})\end{array}$ & Mycelial characters \\
\hline 1 & $\mathrm{MP}_{1}$ & 88.25 & 178.25 & 96.50 & Black grey profusely growth \\
\hline 2 & $\mathrm{MP}_{2}$ & 72.60 & 147.25 & 78.20 & Black profusely aerial growth \\
\hline 3 & $\mathrm{MP}_{3}$ & 83.50 & 160.25 & 80.80 & Black grey profusely aerial growth \\
\hline 4 & $\mathrm{MP}_{4}$ & 86.75 & 168.75 & 86.20 & Grey profusely aerial growth \\
\hline 5 & $\mathrm{MP}_{5}$ & 84.25 & 164.75 & 83.60 & Light grey scanty aerial growth \\
\hline 6 & $\mathrm{MP}_{6}$ & 84.11 & 162.50 & 82.40 & Black scanty aerial growth \\
\hline 7 & $\mathrm{MP}_{7}$ & 80.60 & 158.25 & 80.06 & Light grey profusely aerial growth \\
\hline 8 & $\mathrm{MP}_{8}$ & 87.00 & 169.00 & 89.60 & White grey profusely aerial growth \\
\hline 9 & $\mathrm{MP}_{9}$ & 82.50 & 159.75 & 80.28 & Black grey profusely aerial growth \\
\hline 10 & $\mathrm{MP}$ & 183.50 & 104.20 & Black grey profusely aerial growth \\
\hline & $\mathrm{S} . \mathrm{Ed}$. & 90.00 & 0.10 & 1.01 & - \\
\hline & $\mathrm{C} . \mathrm{D} .(\mathrm{p}=0.05)$ & 0.14 & 0.22 & 2.12 & \\
\hline
\end{tabular}

Table.4 Effect of inoculum level of M. phaseolina on the root rot incidence of cowpea (Pot culture)

\begin{tabular}{|c|c|c|c|c|c|}
\hline \multirow{2}{*}{ Tr.No. } & \multirow{2}{*}{$\begin{array}{l}\text { Inoculum } \\
\text { level (\%) }\end{array}$} & \multicolumn{3}{|c|}{ Per cent infection } & \multirow{2}{*}{ Mean } \\
\cline { 3 - 6 } & 1.0 & 30 DAS & 60 DAS & 90DAS & 13.58 \\
\hline 1 & 3.0 & 21.81 & 12.00 & 18.70 & 28.73 \\
\hline 2 & 5.0 & 25.65 & 30.00 & 34.40 & 38.23 \\
\hline 3 & 7.0 & 26.64 & 38.00 & 51.04 & 39.24 \\
\hline 4 & 10.0 & 25.54 & 39.00 & 52.10 & 38.30 \\
\hline 5 & Control & 00.00 & 00.00 & 51.24 & 00.00 \\
\hline 6 & S.Ed. & 1.22 & 1.84 & 2.61 & - \\
\hline
\end{tabular}

DAS - Days after sowing 
Among the five different levels of inoculums tested, the 7 per cent inoculum conc. $\left(\mathrm{T}_{4}\right)$ recorded the maximum per cent infection at 30, 60 and 90 DAS (26.64, 39.0 and 52.1\%) which was on par with that of five per cent level of inoculum. The one and three per cent levels recorded only moderate incidence.

The subsequent studies were carried out with five per cent level of the inoculum. Similar to the present observations McCain and Scharpf (1989) and Moradia (2011) have found that increasing sclerotial population of $M$. phaseolina increased the infection and colonization in conifers sunflower and groundnut respectively. Umamaheswari et al., (2002) observed that in groundnut root infection was severely increased by increasing inoculums density of $M$. phaseolina. Similarly, Suriachandraselvam and Seetharaman (2003) reported that increase in the inoculums level of $M$. phaseolina by artificial inoculation increased the root rot incidence in blackgram. In spite of being a mono-specific genus, $M$. phaseolina exhibits a high degree of morphological (Mayek-Perez et al., 1997), pathogenic (Su et al., 2001), physiological (Mihail and Taylor, 1995) and genetic (Babu et al., 2007) variability probably due to the presence of heterokaryosis (Beas-Fernandez et al., 2006).

\section{References}

Ahlawat, I.P.S., and Shivkumar, B.G. 2005. Kharif Pulses.In Text book of field crops production. Dr. Rajendra Prasad (eds.) Indian Council of Agri. Res., New Delhi, India.

Anil Kumar Singh, Bhatt, B.P., Sundaram, P. K., Santosh Kumar, Bahrati, R.C., Naresh Chandra and Mathura Rai. 2012. Study of Site Specific Nutrients Management of Cowpea Seed. Approaches to Plant Disease Control. Chet, I., John wiley \& Sons, New York, USA.

Awurum, A.N., Enyiukwu, D.N. 2013. Evaluation of the seed-dressing potentials of phytochemicals from \Carica papaya and Piper guineenseon the germination of cowpea (Vigna unguiculata L. Walp) seeds and incidence of the seed-borne fungi. Continental J. of Agric. Sci. 7(1): 29-35.

Babu, B.K., Srivastava, A.K., Saxena, A.K. and Arora, D.K. 2007. Identification and detection of Macrophomina phaseolina by using species specific oligonucleotide primers and probe. Mycologia.99: 733-739.

Beas-Fernandez, R., De Santiago, A., HernandezDelgado, S., and Mayek-Perez, N. 2006. Characterization of Mexican and nonMexican isolates of Macrophomina phaseolina based on morphological characteristics, pathogenicity on bean seeds and endoglucanase genes. J. Plant Pathol., 88: 53-60.

Chowdary, N.B. 2009. Pathogenicity of various isolates of Macrophomina phaseolina on mulberry (Morus spp.).Arch. Phytopathol. Pl. Prot., 42(11): 1051-1054.

Cruz Jimenez. 2011. Influence of soils, nutrition, and water relations upon charcoal rot disease processes in Kansas, M.Sc. Thesis, Kansas State University, Kansas.

Dhingra, O.D. and Sinclair, J.B. 1978. Biology and pathology of Macrophomina phaseolina. Universidade Federal de vicosapressvicosa, M.G. Barzil. p. 125.

Edraki, V. and Banihashemi, Z. 2010.Phenotypic diversity among isolates of Macrophomina phaseolina and its relation to pathogenicity. Iran. J. Plant Path., 46(4): 93-100.

Emechebe, A.M., and Lagoke, S.T.O. 2002. Recent advances in research of cowpea disease. In: Challenges and opportunities for enhancing sustainable cowpea production adited by Fatokun C.A., Tarawali, S.A. Singh, B.B., Komawa, P.M. and Tamo. M. 94-123.

Fang, J., Chao, C.C.C., Roberts, P.A. and Elhers, J. 2007. Genetic diversity of cowpea (Vigna unguiculata(L.)Walp.)in four West African and USA breeding programs as determined by AFLP analysis. Genetic Res. Crop Evolution, 54(6): 1197209.

FAOSTAT. 2013. Agricultural Production. Food and Agriculture Organization of the United Nations. http://www.faostat.fao.org. Cited 26 April 2010. 
Fatokum, C.A., Taarawale, S.S., Singh, B.B., Korimawa, P.M., \& Tamo, M. 2000. Challenges and opportunities for enhancing sustainable cowpea production.Proc. Of the world cowpea conference III held at IITA Ibadan, Nigeria 4-8 September 2000, pp. 214-220.

Ghosh, S.K. and Sen, C. 1973. Comparitive physiological studies on four isolates of Macrophomina phaseolina. Indian Phytopath., 26: 615-621.

Gomez, C. 2004. Manual for Cowpea: Post harvest operations. FAO, Rome, Italy.

Hooda, I. and Grover, R.K. 1982. Studies on different isolates, age and quantity of inoculum of Rhizoctonia bataticola in relation to disease development in mungbean. Indian Phytopath., 35: 619-623.

Ijaz, S., Sadaqat, H.A. and Khan, M.N. 2012.A review of the impact of charcoal rot (Macrophomina phaseolina) on sunflower. J. Agrl. Sci., 1-6.

Mayek-Pérez N., Garcia-Espinosa R., LópezCastañeda C., Acosta-Gallegos, J.A., Simpson J., 2002. Water relations, histopathology, and growth of common bean (Phaseolus vulgaris L.) during pathogenesis of Macrophomina phaseolina under drought stress. Physiol. Mol. Plant Pathol., 60: 185-195.

Mayek-Perez, N., Lopez-Castaneda, C.and Acosta-Gallegos, J.A. 1997. Variation in vitro cultural characteristics of Macrophomina phaseolina isolates and its virulence on common bean. Agrociencia, 31 187-195.

Mc Cain, A.H. and R.F. Scharpf. 1989. Effect of inoculum density of Macrophomina phaseolina on seedling susceptibility of six conifer species. Eur. J. For. Pathol., 19: 119-123.

Mihail, J.D. and Taylor, S.J. 1995. Interpreting of variability among isolates of Macrophomina phaseolina in patogenicity, pycnidium production, and chlorate utilization. Canadian J. Botany, 73: 15961603.

Mirza, M.S. 1984. Occurrence of sunflower diseases in Pakistan in 1980-83.In: Proceedings of the National Sunflower Workshop, PARC, pp. 31-32.
Monga, D. and Sheo, Raj. 1994. Cultural and pathogenic variations in the isolates of Rhizoctonia species causing root rot of cotton. Indian Phytopath., 47: 403-408.

Moradia, A.M. 2011. Management of Macrophomina phaseolina in groundnut through systemic fungicides. Inter. J. Plant Prote., 4(1): 212-213

Ng, N. Q., and Marechal. R. 1985. Cowpea Taxonomy, Origen and germplasm. In Singh, R.S., Rachie, K.O.(Eds) Cowpea research production and utilization. Jhon Wiley and Sons, New York. pp. 11-21.

Nirmal, R., Kalloo, G., \& Kumar, R. 2001. Diet versatility in cowpea (Vigna unguiculata) genotypes. Indian J. Agri. Sci., 71P: 598601.

Rangaswami, G. 1972. Diseases of Crop Plants in India, Prentice Hall of India Pvt. Ltd., New Delhi, p.520.

Ratnoo, R.S., Jain, K.L. and Bhatnagar, M.K. 1997. Effect of atmospheric temperature on the development of ash-gray stem blight of cowpea. J. Mycol. Pl. Pathol., 27(1): 90-91.

Rauf, B.A., 2000. Seed borne disease problems of legume crops in Pakistan. Pakistan. J. Sci. and Indust. Res. 43: 249-254.

Rayatpanah, S. and Dalili, S.A. 2012. Diversity of Macrophomina phaseolina (Tassi) Goid.based on chlorate phenotypes and pathogenicity. Inter. J. Biol., 4(2): 54- 63.

Rettinasababady, C. 1996. Studies on the root rot of blackgram (Vigna mungo (L.) Hepper) caused by Macrophomina phaseolina (Tassi.) Goid.under rice fallow. Ph.D. Thesis, Tamil Nadu Agricultural University, Coimbatore, India, p. 171.

Rettinasababady, C. and Ramadoss, N. 1999. Occurrences of root rot in rice fallow blackgram (Macrophomina phaseolina). Legume Res. 22: 139-140.

Rettinasababady, C. and Ramadoss, N. 2000. Biological protection of rice fallow blackgram against root rot disease (Macrophomina phaseolina). Legume Res., 23: 245-248.

Riker, A.J. and Riker, A.S. 1936. Introduction to research on plant diseases. John. S. Swift, C.M.C., New York. p. 117.

Salik, N.K. 2007. Macrophomina phaseolina as causal agent for Charcoal rot of sunflower. 
Indian J. Mycol. Pl. Pathol., 2: $111-118$.

Sankar, P. 1994. Biological control of sesamum root rot caused by Macrophomina phaseolina(Tassi.) Goid. M.Sc. (Ag.) Thesis, Tamil Nadu Agricultural University, Coimbatore, India, p. 141.

Sharma, P. and Dureja, P. 2004. Evaluation of Trichoderma harzianum and Trichoderma viride isolates at BCA Pathogen Crop Interface. J. Mycol. Plant Pathol., 34(1): 47-55.

Sharmishha, P., Bhavneet Kaur, Neeraj Dilbaghi and Ashok Chaudhury. 2004. Cultural and pathogeinc variation in the charcoal root rot pathogen from cluster bean. Ann. Agri Bio Res., 9(2): 217-221.

Shekhar, M., Sharma, R.C. Lokendra, S. and Ram, D. 2006. Morphological and pathogenic variability of Macrophomina phaseolina(Tassi.) Goid incitant of charcoal rot of maize in India. Indian Phytopathol., 59(4): 453-459.

Singh, B.B., Ehlers J.D., Sharma, B., FreireFilho, F.R. 2002. Recent progress in cowpea breeding. In. Fatokun C. A., Tarawali S.A., Singh, B.B., Kormawa, P.M and Tamo, M. (eds) Challenges and opportunity for enhancing sustainable cowpea production. Proceedings of the World Cowpea Conference iii held at International Institute of Tropical Agriculure (IITA), Ibadan, Nigeria, 4-8 September 2000. IITA Ibadan Nigeria.

Singh PK, Chittpurna, Ashish, Sharma V, Patil PB, Korpole S. 2012. Identification, purification and characterization of laterosporulin, a novel bacteriocin produced by Brevibacillus sp. Pl. Path., 7(3): 31498.

Su, G., Suh, S.O., Schneider, R.W. and Russin,
J.S. 2001. Host specialization in the charcoal rot fungus Macrophomina phaseolina. Phytopatholog, 91: 120-126.

Sundravadana, S., Alice, D. and Thirumurugan, S. 2012. Exploration of variability in colony morphology and virulence of Rhizoctonia bataticola isolates causing dry root rot of pulses. Global J. Bio-sci. Biotechnol., 1(1): 2278-9103.

Suriachandraselvan, M. and Seetharaman, K. 2003.Effect of culture media on growth and sclerotial production of different isolates of Macrophomina phaseolina infecting sunflower. J. Mycol. Pl. Pathol., 3: 226229.

Tandel, D.H., Sabalpara, A.N. and Patel, R.C. 2012.Evaluation of different solid and liquid media for the growth and sclerotial formation of Macrophomina phaseolina (Tassi) Goidin vitro. The Bioscan, 7(4): 743-745.

Umamaheshwari, C. 1991. Biological control of root rot of groundnut (Arachis hypogaea L.) caused by Macrophomina phaseolina (Maub.) Ashby.M.Sc. (Ag.) Thesis, Tamil Nadu Agricultural University, Coimbatore, India. p. 93.

Umamaheshwari, M.P., Muthusamy, M. and Alice, D. 2002.Evaluation of antagonists against jasmine wilt caused by Sclerotium rolfsii. J. Biol. Control, 16: 135-140.

Vilela, U.M., Dal, P. and Delgada, J.M.A. 1987. Pathogenic and characterization of different isolates of Macrophomina phaseolina causal agent of charcoal root rot of cotton under conditions in Piura. Peru Fitopathologia, 22: 1-9.

\section{How to cite this article:}

Mohanapriya, R., R. Naveenkumar and Balabaskar, P. 2017. Survey, Virulence and Pathogenicity of Root Rot Incidence of Cowpea in Selected Districts of Tamilnadu caused by Macrophomina phaseolina (Tassi.) Goid. Int.J.Curr.Microbiol.App.Sci. 6(3): 694-705. doi: https://doi.org/10.20546/ijcmas.2017.603.080 